\title{
Simultaneous Estimation of Emtricitabine and Tenofovir Disoproxil Fumarate in Tablet Dosage Form by Reverse Phase High-performance Liquid Chromatography
}

Bala Rami Reddy.Yenumula ${ }^{1 * \#}$, Mutta Reddy.Singampalli² and Bala Sekhara Reddy.Challa ${ }^{3 \#}$

${ }^{1}$ St. Ignatious Degree College, Gurazala, Guntur-522415, India

${ }^{2}$ Womens Degree College, Guntur-522004, India

${ }^{3}$ Vagdevi College of Pharmacy, Gurazala, Guntur-522415, India

${ }^{\text {\#} A u t h o r s ~ a r e ~ e q u a l l y ~ c o n t r i b u t e d ~}$

Received: August 14, 2015; Accepted: December 07, 2015; Published: December 10, 2015

*Corresponding authors: Bala Rami Reddy Yenumula, St.Ignatious Degree College, Gurazala, Guntur-522415, India, E-mail: balaram.yenumula@ gmail.com; drchalla2121@gmail.com

\begin{abstract}
A simple, rapid reversed-phase high performance liquid chromatographic method had been developed and validated for estimation of emtricitabine and tenofovir disoproxil fumarate in tablet dosage form. The estimation was carried out on PhenomenexLuna C18 $(25 \mathrm{~cm} \times 4.60 \mathrm{~mm}$, particle size $5 \mu \mathrm{m})$ column with a mixture of $10 \mathrm{mM}$ phosphate buffer ( $\mathrm{pH}$ 6.8): Acetonitrile; 40: 60 $(\mathrm{v} / \mathrm{v})$ as mobile phase. UV detection was performed at $260 \mathrm{~nm}$. The method was validated for linearity, accuracy, precision, specificity and sensitivity as per ICH norms. The developed and validated method was successfully used for the quantitative analysis of commercially available dosage form. The retention time was 2.81 and $7.42 \mathrm{~min}$ for emtricitabine and tenofovir disoproxil fumarate respectively and total run time was $10 \mathrm{~min}$. at a flow rate of $1.0 \mathrm{~mL} /$ min. The calibration curve was linear over the concentration range of $40.00-240.00 \mu \mathrm{g} / \mathrm{mL}$ for emtricitabine and $60.00-360.00 \mu \mathrm{g} /$ $\mathrm{mL}$ for tenofovir disoproxil fumarate. The LOD and LOQ values were found to be 1.54 and $4.54 \mu \mathrm{g} / \mathrm{mL}$ for emtricitabine and 4.60 and $13.65 \mu \mathrm{g} / \mathrm{mL}$ for tenofovir disoproxil fumarate respectively. The high percentage of recovery and low percentage coefficient of variance confirm the suitability of the method for the simultaneous estimation of emtricitabine and tenofovir disoproxil fumarate in tablet dosage form.
\end{abstract}

Keywords: Emtricitabine; Tenofovir disoproxil fumarate; RPHPLC; Validation

\section{Introduction}

Emtricitabine (ETB) is a nucleoside reverse transcriptase inhibitor (NRTIs). Chemically it is 5-fluoro-1-(2R, 5S)-[2(hydroxymethyl)-1,3-oxathiolan-5-yl]cytosine (Figure 1). FTC is the (-) enantiomer of thio analog of cytidine which differs from other cytidine analogs, in that it has fluorine in 5th position. FTC is an antiviral agent used for the prevention of perinatal HIV-1 reverse transcriptase [1]. It is also active against Hepatitis B virus $[2,3]$.

Tenofovir disoproxil Fumarate (TDF) is fumaric acid salt of the bisisopropoxycarbonyl- oxymethyl ester derivative of tenofovir. Chemically it is 9-[(R)-2-[[(isopropoxycarbonyl) oxy]-methoxy] phosphiny]methoxy]propyl]adenine fumarate (Figure 1). It is used in combination with other antiretroviral for the treatment of HIV infection [2,3]

Literature survey reveals that few RP-HPLC [4-6] methods are reported for estimation of ETB, TDF and efavirenz in pharmaceutical formulation. TDF is estimated individually by UV [7], derivative-HPLC [8], HPTLC [9] in pharmaceutical formulation. ETB, TDF were estimated in biological matrices by HPLC [11,12] and LC/ MS/ MS [13-25], methods. The reported methods [4-6] for estimation of ETB, TDF in pharmaceutical formulations have some drawbacks in terms of sensitivity, ruggedness and robustness. The purpose of this study was to develop simple, rapid, precise and accurate RP-HPLC method for the simultaneous estimation of both the drugs in combined tablet dosage form.

\section{Experimental}

\section{Apparatus}

RP-HPLC was performed with an Agilent chromatographic system equipped with 1200 series isocratic pump UV-visible and a Rheodyne universal loop injector of injection capacity $50 \mu \mathrm{L}$. The monitoring software was Ezichrome Elite. The equipment was controlled by a PC workstation. Compounds were separated

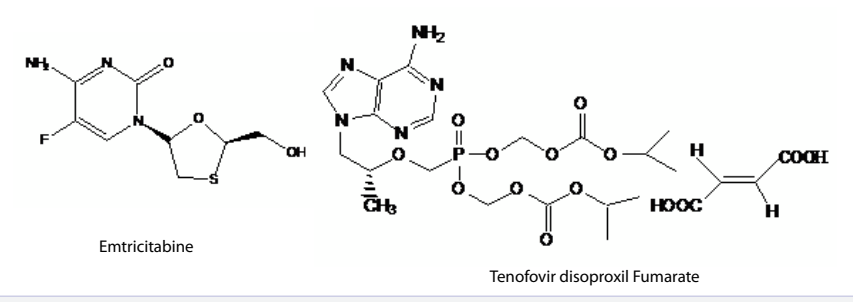

Figure 1: Chemical structures of ETB and TDF. 
on a $25 \mathrm{~cm} \times 4.6 \mathrm{~mm}$ i.d, 5- $\mu \mathrm{m}$ particle, Phenomenex-Luna $\mathrm{C}_{18}$ column under reversed-phase partition chromatographic conditions. The flow rate was $1.0 \mathrm{~mL} / \mathrm{min}$ and injection volume was $20 \mu \mathrm{L}$, analyte were monitored at $260 \mathrm{~nm}$ and run time was $10 \mathrm{~min}$.

\section{Chemicals and reagents}

Working Standards of pharmaceutical grade ETB and TDF were obtained as gift samples from Micro labs, Bangalore. The tablet dosage form, manufactured by Hetero Drugs Limited, Hyderabad, India (Label claim: ETB $200 \mathrm{mg}$ and TDF $300 \mathrm{mg}$ ), was procured from the local pharmacy. All the chemicals and reagents used were of HPLC grade and purchased from Merck, Mumbai, India.

\section{Mobile phase}

The mobile phase selected was acetonitrile: $10 \mathrm{mM}$ phosphate buffer ( $\mathrm{pH}$ 6.8) (60:40, v/ v), and filtered through $0.45 \mu \mathrm{m}$ pore size membrane filter. Before analysis mobile phase was degassed.

\section{Preparation of standard stock solution}

Standard stock solution of Emtricitabine and Tenofovir pure drug prepared by accurately weighing about $100 \mathrm{mg}$ drugs and transferring in to $100 \mathrm{~mL}$ volumetric flask and dissolved in acetonitrile.

\section{Construction of calibration curve}

A series of standard concentrations were prepared from 50 $\%$ to $150 \%$ of the target concentration of ETB and TDF. Linearity was assessed by performing single measurement at several analyte concentration varying quantities of stock standard solution diluted with the mobile phase to get final concentrations of $40,80,120,160,200,240 \mu \mathrm{g} / \mathrm{mL}$ of ETB and $60,120,180,240$, $300,360 \mu \mathrm{g} / \mathrm{mL}$ of TDF.

\section{Sample preparation}

A total of 20 tablets were accurately weighed and powdered in a mortar. An amount equivalent to $66.5 \mathrm{mg}$ (tablet Containing $20 \mathrm{mg}$ of ETB and $30 \mathrm{mg}$ of TDF) was transferred to $50 \mathrm{~mL}$ volumetric flask and added $10 \mathrm{ml}$ of mobile phase and sonicated for $10 \mathrm{~min}$ and make up to $50 \mathrm{~mL}$ with mobile phase. The solution was filtered $0.45 \mu \mathrm{m}$ pore size membrane filter. The filtered sample solution $5 \mathrm{~mL}$ was diluted to $10 \mathrm{~mL}$ with mobile phase to get the solution containing ETB and TDF in $200 \& 300 \mu \mathrm{g} / \mathrm{mL}$ proportions respectively. The test solution was injected in to HPLC and \% assay was calculated. The results are depicted in Table 1.

\section{Result and Discussion}

\section{HPLC method development and optimization}

Column chemistry, solvent type, solvent strength, detection wavelength and flow rate were varied to determine the chromatographic conditions giving the best separation. The mobile phase conditions were optimized so that the components were not interfered from the solvent and excipients.

After series of trials with various $\mathrm{C}_{8}$ and $\mathrm{C}_{18}$ columns, the final choice of stationary phase giving satisfactory resolution and run time was the reversed phase Phenomenex-Luna $\mathrm{C}_{18}$ column. Mobile phase and flow rate selection was based on peak parameters (height, area, tailing, theoretical plates, capacity factor and resolution) and run time. The best result was obtained by use of acetonitrile: $10 \mathrm{mM}$ phosphate buffer (pH 6.8) (60:40, v/ v), with $1.0 \mathrm{~mL} / \mathrm{min}$. From the overlain UV spectra, suitable wavelength considered for monitoring the drugs was $260 \mathrm{~nm}$ (Figure 2). Solutions of FTB and TDF in diluents were also injected directly for HPLC analysis and the responses (peak area) were recorded. It was observed that there was no interference from the mobile phase or baseline disturbances and both the analytes absorbed well at $260 \mathrm{~nm}$. Under the optimum chromatographic conditions, the retention time obtained for ETB and TDF were 2.81 and 7.42 min respectively. The chromatogram of placebo, standard and test formulation was depicted Figure 2-4.

\section{Method Validation}

The method was validated for linearity, accuracy, precision, repeatability, selectivity and specificity study as per ICH norms. All the validation studies were carried out by replicate injection of the sample and standard solutions [19].

\section{Selectivity and Specificity}

The selectivity was checked by injecting placebo solution and compared with standard chromatogram of ETB and TDF. Specificity of the method was assessed by comparing the chromatograms obtained from standard drugs, with the chromatogram obtained from tablet solutions. As the retention time of standard drugs and the retention time of the drugs in sample solution was same, so the method was specific. The developed method was found specific and selective, as there was no interference of excipients found.

Linearity: Linearity was found to be $40-240 \mu \mathrm{g} / \mathrm{mL}$ for ETB and 60-360 $\mu \mathrm{g} / \mathrm{mL}$ for TDF. The linear regression for ETC and TDF were $\left(r^{2}=0.9934\right)$ and $\quad\left(r^{2}=0.9999\right)$. The results were depicted in Table 2 and Figure 5,6.

Accuracy: Accuracy of developed method was confirmed by doing recovery study as per ICH norms at three different concentration levels $80 \%, 100 \%$ and $120 \%$ by replicate analysis $(n=3)$. The result of accuracy study was reported in Table 3. From the recovery study it was clear that the method is very accurate for quantitative estimation of ETB and TDF in tablet dosage form as all the statistical results were within the range of acceptance. The results were depicted in Table 3 .

Table 1: Assay of Tablet Formulation.

\begin{tabular}{|c|c|c|c|c|c|c|}
\hline Tablet & \multicolumn{2}{|c|}{ Label claimed (mg) } & \multicolumn{3}{|c|}{ Conc. found (mg) } & \% Assay \\
\hline ETOF & ETB & TDF & ETB & TDF & ETB & TDF \\
\cline { 2 - 6 } Tablets & 20.0 & 30.0 & 20.05 & 29.98 & 100.21 \\
\hline
\end{tabular}




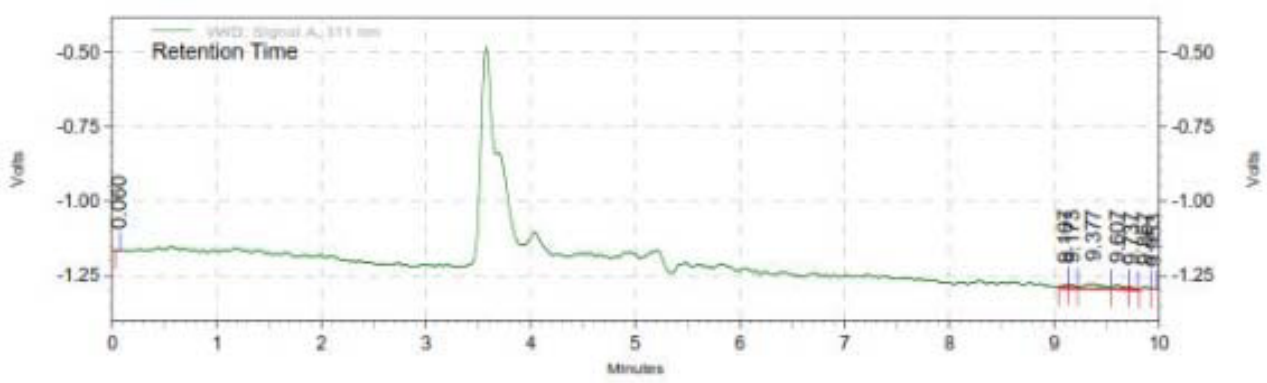

Figure 2: Chromatogram of Placebo.

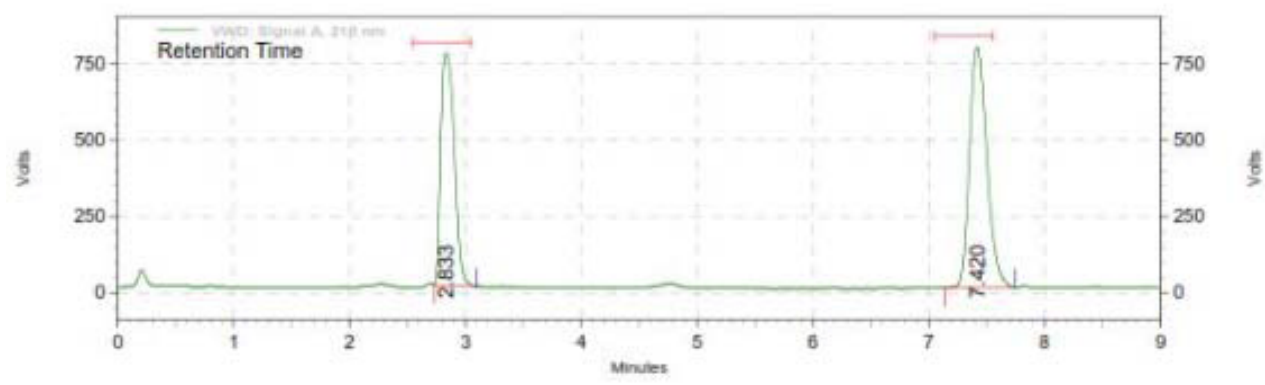

Figure 3: Chromatogram of standard ETB and TDF.

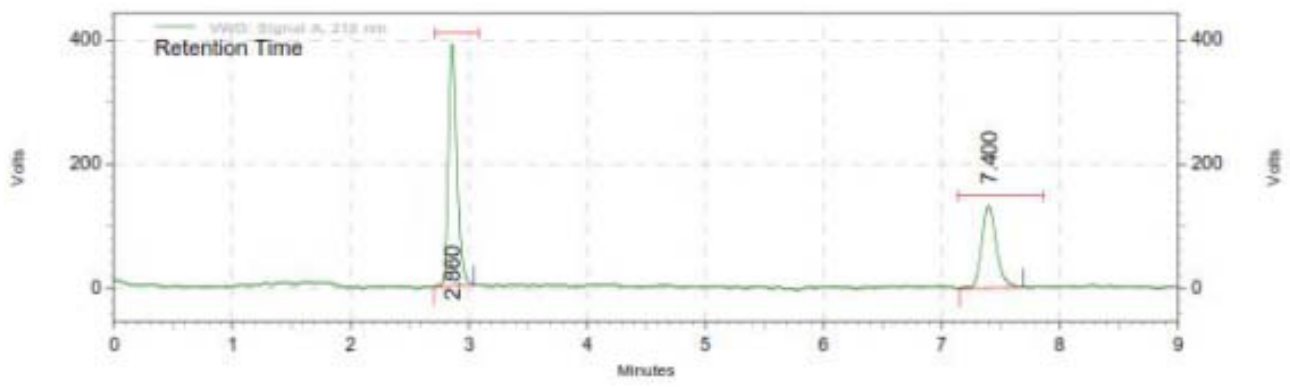

Figure 4: Chromatogram of ETB and TDF in test formulation.

Table 2: Linearity and range of ETB and TDF.

\begin{tabular}{|c|c|c|c|c|}
\hline S.No. & $\begin{array}{c}\text { Concentration } \\
\mu \mathrm{g} / \mathrm{ml}\end{array}$ & $\begin{array}{c}\text { Area of } \\
\text { Emtricitabine }\end{array}$ & $\begin{array}{c}\text { Concentration } \\
\mu \mathrm{g} / \mathrm{ml}\end{array}$ & $\begin{array}{l}\text { Area of } \\
\text { Tenofovir }\end{array}$ \\
\hline 1 & 40 & 22988.567 & 60 & 16998.424 \\
\hline 2 & 80 & 47605.237 & 120 & 33602.702 \\
\hline 3 & 120 & 68028.039 & 180 & 50459.14 \\
\hline 4 & 160 & 90704.169 & 240 & 67137.714 \\
\hline 5 & 200 & 102120.617 & 300 & 84014.837 \\
\hline 6 & 240 & 130654.429 & 360 & 101710.108 \\
\hline $\begin{array}{c}\text { Concentration range } \\
\mu \mathrm{g} / \mathrm{ml}\end{array}$ & \multicolumn{2}{|c|}{$40-240$} & \multicolumn{2}{|c|}{$60-360$} \\
\hline Slope $(\mathrm{m})$ & \multicolumn{2}{|c|}{543.85} & \multicolumn{2}{|c|}{281.04} \\
\hline Correlation co-efficient $\left(\mathrm{r}^{2}\right)$ & \multicolumn{2}{|c|}{0.993} & \multicolumn{2}{|c|}{0.999} \\
\hline
\end{tabular}

Citation: Reddy BRY, Reddy MT, Reddy BSC (2015) Simultaneous Estimation of Emtricitabine and Tenofovir Disoproxil Fumarate in Tablet Dosage Form by Reverse Phase High-performance Liquid Chromatography. Int. J. Anal. Tech 1(1): 6.

DOI: http://dx.doi.org/10.15226/2471-3627/1/1/00104 


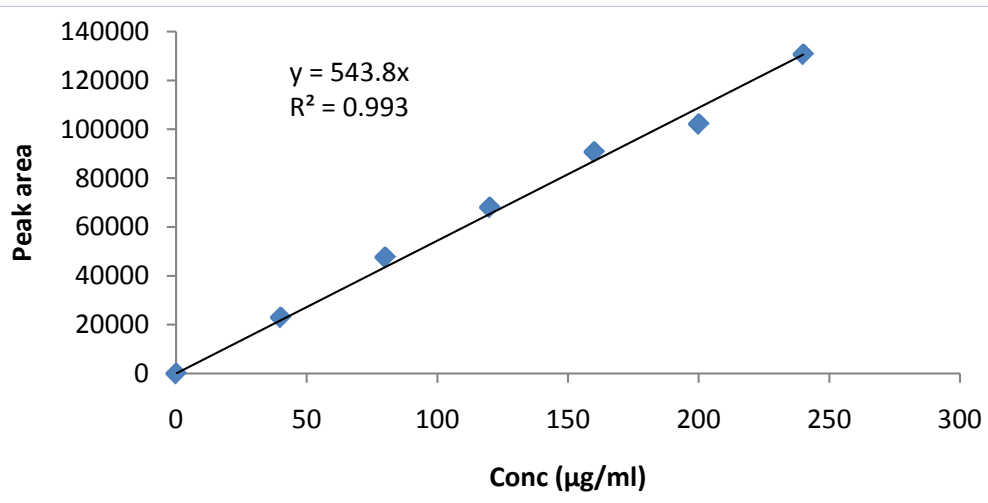

Figure 5: Linearity of Emtricitabine.

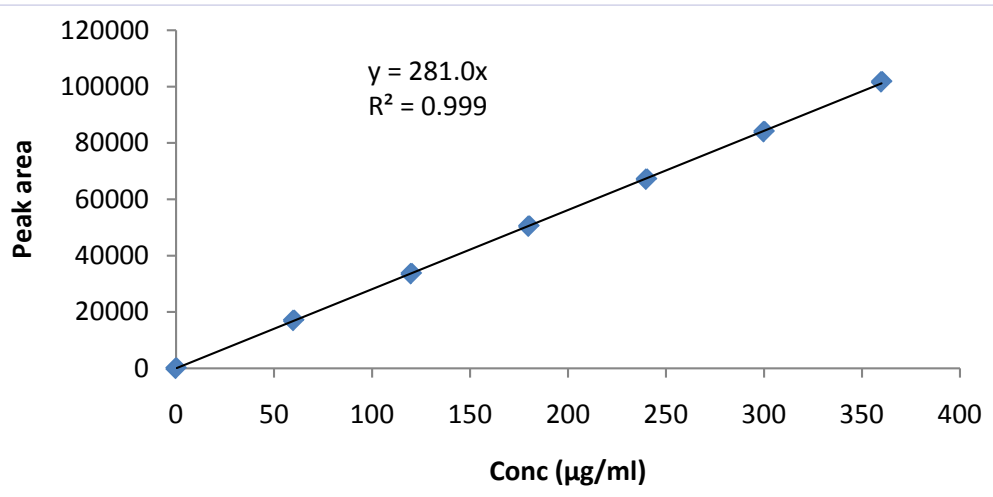

Figure 6: Linearity of Tenofovir.

Table 3: Recovery Studies.

\begin{tabular}{|c|c|c|c|c|c|c|c|}
\hline $\begin{array}{l}\text { Level of \% } \\
\text { recovery }\end{array}$ & $\begin{array}{l}\text { Target Conc. }(\mu \mathrm{g} / \\
\mathrm{ml})\end{array}$ & $\begin{array}{c}\text { Amount of drug spiked } \\
(\mu \mathrm{g} / \mathrm{ml})\end{array}$ & $\begin{array}{l}\text { Drug recovered } \\
(\mu \mathrm{g} / \mathrm{ml})\end{array}$ & \%Recovery & Mean & SD & \%RSD \\
\hline \multirow{3}{*}{80} & \multirow{3}{*}{100} & \multirow{3}{*}{80} & 181.13 & 100.62 & \multirow{3}{*}{99.95} & \multirow{3}{*}{1.42} & \multirow{3}{*}{1.27} \\
\hline & & & 180.01 & 100.22 & & & \\
\hline & & & 179.85 & 99.98 & & & \\
\hline \multirow{3}{*}{100} & \multirow{3}{*}{100} & \multirow{3}{*}{100} & 200.10 & 100.21 & \multirow{3}{*}{100.22} & \multirow{3}{*}{1.23} & \multirow{3}{*}{1.12} \\
\hline & & & 202.21 & 100.23 & & & \\
\hline & & & 200.11 & 100.21 & & & \\
\hline \multirow{3}{*}{120} & \multirow{3}{*}{100} & \multirow{3}{*}{120} & 221.21 & 101.15 & \multirow{3}{*}{100.32} & \multirow{3}{*}{1.15} & \multirow{3}{*}{1.46} \\
\hline & & & 220.34 & 100.33 & & & \\
\hline & & & 220.41 & 100.42 & & & \\
\hline
\end{tabular}

Table 4: Recovery Studies.

\begin{tabular}{|l|l|l|l|l|}
\hline \multirow{2}{*}{ Sample. No } & \multicolumn{2}{|c|}{$\begin{array}{c}\text { Intra day } \\
\text { \%Label Claim }\end{array}$} & & \multicolumn{2}{c|}{ \%Ller day } \\
\cline { 2 - 4 } & & TDF & ETB & TDF \\
\hline & ETB & 100.21 & 99.67 & 99.541 \\
\hline $\mathbf{1}$ & 100.31 & 99.61 & 99.12 & 99.93 \\
\hline $\mathbf{3}$ & 99.41 & 100.02 & 100.42 & 100.35 \\
\hline $\mathbf{4}$ & 99.34 & 100.05 & 99.98 & 99.76 \\
\hline $\mathbf{5}$ & 99.22 & 100.08 & 100.1 & 100.43 \\
\hline $\mathbf{6}$ & 100.33 & 99.99 & 100.22 & 99.99 \\
\hline Mean & 100.14 & 100.21 & 99.26 & 99.54 \\
\hline S.D & 99.75 & 0.226247 & 0.3742 & 0.3742 \\
\hline \% R.S.D & 0.2262 & 0.2264 & 0.3742 & 0.3742 \\
\hline
\end{tabular}


Precision: The concentrations of both the drugs were measured three times on the same day at intervals of $1 \mathrm{~h}$ and on three different days for intra and interday study respectively. The results are depicted in Table 4 .

Limit of detection and Limit of Quantification: LOD is found to be $1.5456 \mu \mathrm{g} / \mathrm{mL}$ for Emtricitabine and $0.0712 \mu \mathrm{g} /$ $\mathrm{mL}$ for Tenofovir and LOQ are found to be $4.5924 \mu \mathrm{g} / \mathrm{mL}$ for Emtricitabine and $13.931 \mu \mathrm{g} / \mathrm{mL}$ for Tenofovir.

\section{Conclusion}

A new, reversed-phase HPLC method has been developed for simultaneous analysis of ETB and TDF in a tablet formulation. It was shown that, the method was linear, accurate, reproducible, repeatable, precise, selective and specific proving the reliability of the method. The run time is relatively short (10 $\mathrm{min})$, which enables rapid determination of many samples in routine and quality control analysis of tablet formulations. Hence, the proposed method was successfully applied to analyze preparation containing ETB and TDF.

\section{Acknowledgement}

The authors are thankful to Origene Life Sciences Pvt Ltd for providing technical assistance and necessary facilities.

\section{References}

1. Budawari S. The Merck Index: An Encyclopedia of Chemicals, Drugs, and Biologicals. In: Merck and Co. Inc. Whitehouse Station. NJ: 2001. 630: 1631-32.

2. Sean Sweetman. Martindale: The Complete Drug Reference. 33 rd Edition, Pharmaceutical Press, London. 2002;620, 642.

3. Gish RG, Trinh H, Leung N, Chan FK, Fried MW, et al. Wright TL Safety and antiviral activity of emtricitabine (FTC) for the chronic hepatitis B infection: a two-year study. J Hepatol. 2005; 43(1): 60-6.

4. Mangoankar K, Desai A. Simultaneous estimation of emtricitabine, tenofovir disoproxil fumarate and Efavirenz from tablets by reverse phase high- performance liquid chromatography method. Indian Drugs. 2008; 45(3): 188-92.

5. Appala NR, Rao VJ, Vanitha PK, Mukilteo K, Srinivasu K. Simultaneous estimation of tenofovir disoproxil, emtricitabine and Efavirenz in tablet dosage form by RP- HPLC. Oriental Journal of Chemistry. 2008; 24(2): 645-650.

6. Raju NA, Begum S. Simultaneous RP-HPLC Method for the Estimation of the Emtricitabine, Tenofovir Disoproxil fumarate and Efavirenz in Tablet Dosage forms. Research J. Pharm. and Tech. 2008; 1(4): 522-25.

7. A SA, H BC, J SS. Application of UV- Spectrophotometric Methods for Estimation of Tenofovir Disoproxil Fumarate in Tablets. Pak J Pharm Sci. 2009; 22(1): 27-9.

8. Sparidans RW, Crommentuyn KM, Schellens JH, Beijnen JH. Liquid chromatographic assay for the antiviral nucleotide analogue tenofovir in plasma using derivatization with chloroacetaldehyde. J Chromatogr B Analyt Technol Biomed Life Sci. 2003; 791(1-2): 227-33.

9. Rezk NL, Crutchley RD, Kashuba AD. Simultaneous quantification of emtricitabine and tenofovir in human plasma using high performance liquid chromatography after solid phase extraction. J Chromatogr B Analyt Technol Biomed Life Sci. 2005; 822(1-2): 201-8.

10. Joshi M, Nikalje AP, Shahed M, Dehghan M. HPTLC method for the simultaneous estimation of emtricitabine and tenofovir in tablet dosage form. Indian J Pharm Sci. 2009; 71(1): 95-7. doi: 10.4103/0250474X.51951.

11. Sentenac S, Fernandez C, Thuillier A, Lechat P, Aymard G. Sensitive determination of tenofovir in human plasma samples using reversedphase liquid- chromatography. J Chromatogr B Analyt Technol Biomed Life Sci. 2003; 793(2): 317-24.

12.PB Kandagal, DH Manjunatha, J Seetharamappa, SS Kalanur. RPHPLC method for the determination of tenofovir in pharmaceutical formulations and spiked human plasma. Analytical Letters. 2008; 41(4): 561-570. DOI: 10.1080/00032710801910742.

13. Delahunty T, Bushman L, Fletcher CV. Sensitive assay for determining plasma tenofovir concentrations by LC/MS/MS. J Chromatogr B Analyt Technol Biomed Life Sci. 2006; 830(1): 6-12.

14. Takahashi M, Kudaka Y, Okumura N, Hirano A, Banno K, Kaneda T. Determination of plasma tenofovir concentrations using a conventional LC-MS method. Biol Pharm Bull. 2007; 30(9): 1784-6.

15. King T, Bushman L, Kiser J, Anderson PL, Ray M, Delahunty T. Liquid chromatography-tandem mass spectrometric determination of tenofovir-diphosphate in human peripheral blood mononuclear cells. J Chromatogr B Analyt Technol Biomed Life Sci. 2006; 843(2): 147-56.

16. Droste JAH, Aarnoutse RE, Burger DM. Determination of Emtricitabine in Human Plasma using HPLC with Fluorometric Detection. Journal of Liquid Chromatography \&amp Related Technologies. 2007; 30(18). DOI: $10.1080 / 10826070701560900$.

17. Seshachalam U, Haribabu B, Chandrasekhar KB. Development and Validation of Stability- indicating liquid chromatographic method for determination of emtricitabine and related impurities in drug substance. J Sep Sci. 2007; 30(7): 999-1004.

18. Gomes NA, Vaidya VV, Pudage A, Joshi SS, Parekh SA. Liquid chromatography-tandem mass spectrometry (LC-MS/MS) method for simultaneous determination of tenofovir and emtricitabine in human plasma and its application to a bioequivalence study. J Pharm Biomed Anal. 2008; 48(3): 918-26. doi: 10.1016/j.jpba.2008.07.022.

19. Nirogi R, Bhyrapuneni G, Kandikere V, Muddana N, Saralaya $\mathrm{R}$, Komarneni $\mathrm{P}$, et al. Pharmacokinetic profiling of Efavirenzemtricitabine-tenofovir fixed dose combination in pregnant and non-pregnant rats. Biopharm Drug Dispos. 2012; 33(5): 265-77. doi: 10.1002/bdd.1794.

20. Parks DA, Jennings HC, Taylor C, Pakes GE, Acosta EP. Steady-state amprenavir, tenofovir, and emtricitabine pharmacokinetics before and after reducing ritonavir boosting of a fosamprenavir/tenofovir/ emtricitabine regimen from $200 \mathrm{mg}$ to $100 \mathrm{mg}$ once daily (TELEX II). HIV Clin Trials. 2009; 10(3): 160-7. doi: 10.1310/hct1003-160.

21. Delahunty T, Bushman L, Robbins B, Fletcher CV. The simultaneous assay of tenofovir and emtricitabine in plasma using LC/MS/MS and isotopically labeled internal standards. J Chromatogr B Analyt Technol Biomed Life Sci. 2009; 877(20-21): 1907-14. doi: 10.1016/j. jchromb.2009.05.029.

22. Kuklenyik Z, Martin A, Pau CP, Garcia-Lerma JG, Heneine W, Pirkle JL. Effect of mobile phase pH and organic content on LC-MS analysis of nucleoside and nucleotide HIV reverse transcriptase inhibitors. J Chromatogr Sci. 2009; 47(5): 365-72.

23. Nirogi R, Bhyrapuneni G, Kandikere V, Mudigonda K, Komarneni P, Aleti R, et al. Simultaneous quantification of a non-nucleoside reverse transcriptase inhibitor Efavirenz, a nucleoside reverse transcriptase inhibitor emtricitabine and a nucleotide reverse transcriptase 
inhibitor tenofovir in plasma by liquid chromatography positive ion electrospray tandem mass spectrometry. Biomed Chromatogr. 2009; 23(4): 371-81. doi: 10.1002/bmc.1125.

24. LeSaux T, Chhun S, Rey E, Launay O, Weiss L, Viard JP, etal. Quantification of seven nucleoside/nucleotide reverse transcriptase inhibitors in human plasma by high-performance liquid chromatography with tandem mass-spectrometry. J Chromatogr B Analyt Technol Biomed Life Sci. 2008; 865(1-2): 81-90. doi: 10.1016/j.jchromb.2008.02.008.
25. Rezk NL, Crutchley RD, Kashuba AD. Simultaneous quantification of emtricitabine and tenofovir in human plasma using highperformance liquid chromatography after solid phase extraction. J Chromatogr B Analyt Technol Biomed Life Sci. 2005; 822(1-2): 201-8.

26. International Conference on Harmonization. ICH Harmonised Tripartite Guidelines-Validation of Analytical Procedures: Methodology. 1997. 